\title{
Predictive and Prognostic Biomarkers of Respiratory Diseases due to Particulate Matter Exposure
}

\author{
Hyo Jeong Kim ${ }^{1}$, Min Gi Choi ${ }^{1}$, Moo Kyun Park ${ }^{2}$, Young Rok Seo ${ }^{1}$ \\ IInstitute of Environmental Medicine for Green Chemistry, Department of Life Science, Dongguk Bio-Med Campus, Dongguk University, Goyang, \\ ${ }^{2}$ Department of Otorhinolaryngology-Head and Neck Surgery, Seoul National University College of Medicine, Seoul, Korea
}

\begin{abstract}
Air pollution is getting severe and concerns about its toxicity effects on airway and lung disease are also increasing. Particulate matter (PM) is major component of air pollutant. It causes respiratory diseases, such as asthma, chronic obstructive pulmonary disease, lung cancer, and so on. PM particles enter the airway and lung by inhalation, causing damages to them. Especially, PM 2.5 can penetrate into the alveolus and pass to the systemic circulation. It can affect the cardiopulmonary system and cause cardiopulmonary disorders. In this review, we focused on PM-inducing toxicity mechanisms in the framework of oxidative stress, inflammation, and epigenetic changes. We also reviewed its correlation with respiratory diseases. In addition, we reviewed biomarkers related to PM-induced respiratory diseases. These biomarkers might be used for disease prediction and early diagnosis. With recent trend of using genomic analysis tools in the field of toxicogenomics, respiratory disease biomarkers associated with PM will be continuously investigated. Effective biomarkers derived from earlier studies and further studies might be utilized to reduce respiratory diseases.
\end{abstract}

(J Cancer Prev 2017;22:6-15)

Key Words: Particulate matter, Biomarker, Oxidative stress, Inflammation, Epigenetic change

\section{INTRODUCTION}

In modern society, development of industry causes environmental pollutions, including air, water, and soil pollutions. Among them, the air pollution has been revealed to be one of the harmful factors affecting human health by various studies. ${ }^{1-4}$ In accordance with World Health Organization (WHO) report, the exposure to air pollutant caused approximate 7 million of death in the world in 2012. ${ }^{5}$ Air pollutants consist of carbon monoxide, volatile organic compounds, persistent free radicals, particulate matter (PM), and so on. ${ }^{6}$ All these substances have some effects on human health. They especially induce lung and heart dysfunctions.

Among these major air pollutants, PM is the most harmful substance to human health by causing various diseases. ${ }^{7,8}$ It is classified as a Group 1 carcinogen (induces carcinogenesis in human body) by International Agency for Research on Cancer. PM induces the premature death in people with heart or lung disease. It also induces nonfatal heart attacks, irregular heartbeat, aggravated asthma, decreased lung function, and increased respiratory symptoms, such as irritation of the airways, coughing, and difficulty breathing.

PM is a complex mixture of extremely small particles and liquid droplet in the atmosphere. ${ }^{9}$ The complex mixture consists of organic carbon, ammonium, nitrates, sulphates, mineral dust, trace elements, and water. These substances exist as particles with diameters of less than $2.5 \mu \mathrm{m}$ or less than $10 \mu \mathrm{m} .^{10,11}$ Particles with diameters of less than $2.5 \mu \mathrm{m}$ are called $\mathrm{PM}_{2.5}$ and those of less than $10 \mu \mathrm{m}$ are called $\mathrm{PM}_{10}{ }^{12} \mathrm{PM}_{10}$ is composed of various dusts from sea salt, soil dust resuspension, construction/

Received December 21, 2016, Revised February 9, 2017, Accepted February 10, 2017

Correspondence to: Young Rok Seo

Institute of Environmental Medicine for Green Chemistry, Department of Life Science, Dongguk Bio-Med Campus, Dongguk University, 32 Dongguk-ro, Ilsandong-gu, Goyang 10326, Korea

Tel: +82-31-961-5172, E-mail: seoyr@dongguk.edu

Copyright (C) 2017 Korean Society of Cancer Prevention

(c) This is an Open Access article distributed under the terms of the Creative Commons Attribution Non-Commercial License (http://creativecommons.org/licenses/by-nc/4.0) which permits unrestricted non-commercial use, distribution, and reproduction in any medium, provided the original work is properly cited. 
demolition, non-exhausted vehicle emissions, and industrial fugitives. ${ }^{13}$ Sources of $\mathrm{PM}_{2.5}$ are primarily emissions from natural event, such as forest fire, and industrial activities, such as mining and construction. Another sources of $\mathrm{PM}_{2.5}$ are secondary particles converted from chemical or gas generated by industrial activities. ${ }^{14}$ Heavy metals, such as $\mathrm{Pb}, \mathrm{Ni}, \mathrm{Cd}, \mathrm{Cr}, \mathrm{V}, \mathrm{Cu}$, and $\mathrm{Mn}$, are well-known as hazardous substances. They are also sources of $\mathrm{PM}_{2.5}{ }^{15}$

Depending on its diameter, PM has detrimental effects on human. It has different transport efficiency and penetration ratio to the respiratory system. ${ }^{16} \mathrm{PM}_{10}$ leads to physical damage to the respiratory system, such as alveolus and larynx. It rarely induces chemical reaction to lung tissue. ${ }^{16}$ It can reach alveolus or bronchioles but cannot penetrate alveolus. In contrast, $\mathrm{PM}_{2.5}$ is able to penetrate into the alveolus and pass to the systemic circulation. It induces both physical and chemical damage to the respiratory system. ${ }^{16}$ Therefore, $\mathrm{PM}_{2.5}$ induces more serious damage to the lung than $\mathrm{PM}_{10}$.

Respiratory system has physical contact with air pollutant by respiration. After being exposed to air pollutant such as PM, inhalation toxicity to the respiratory system might be occured. Numerous research studies have suggested that PM is associated with respiratory toxicity in in vitro, in vivo, and epidemiological studies. ${ }^{17-21} \mathrm{PM}$ can induce oxidative stress and inflammation on respiratory organ tissue. ${ }^{22-25}$ It triggers the development and exacerbation of diverse diseases of the respiratory system, such as asthma, ${ }^{26,27}$ chronic obstructive pulmonary disease (COPD), ${ }^{28-30}$ and so on. Besides, PM can generate reactive oxygen species (ROS) and some oxidative metabolite, causing oxidative stress. $^{31}$ It damages DNA and causes epigenetic changes. ${ }^{32,33}$
According to this reason, PM can eventually induce cancer (Fig. 1). ${ }^{34}$

Once lung is damaged by chemical such as PM, regeneration of lung to normal state is almost impossible. Thus, prediction and early diagnosis of lung diseases are important and imperatively necessary. Biomarkers can be used for disease prediction. ${ }^{35}$ Various epigenetic biomarkers of lung diseases induced by PM exposure have been discovered in recent researches. ${ }^{36.37}$ Epigenetic changes do not alter the DNA sequences. However, they can modify methylation or acetylation of DNA and histone protein, and then induces changes in DNA structure and gene expression. In this review, we focused on PM-inducing toxicity mechanisms in the framework of oxidative stress, inflammation, and epigenetic changes. We also reviewed its correlation with respiratory diseases (Fig. 1). In addition, we reviewed biomarkers related to PM-induced respiratory diseases. These biomarkers might be used for disease prediction and early diagnosis.

\section{TOXIC EFFECTS OF PARTICULATE MATTER ON RESPIRATORY SYSTEM}

\section{Oxidative stress}

Oxidative stress can be defined as damage resulting from imbalance of oxidation and reduction status of the body. ${ }^{38}$ As a result of oxidation, ROS can react with other molecules. Organism has antioxidant defense system for maintaining the stability of redox homeostasis. ${ }^{38}$ However, antioxidant system cannot overcome the effect of excessively produced ROS. ${ }^{38}$ Excessive ROS has various detrimental effects on the body, including cell function impairment and cell death. ${ }^{38}$ In human,

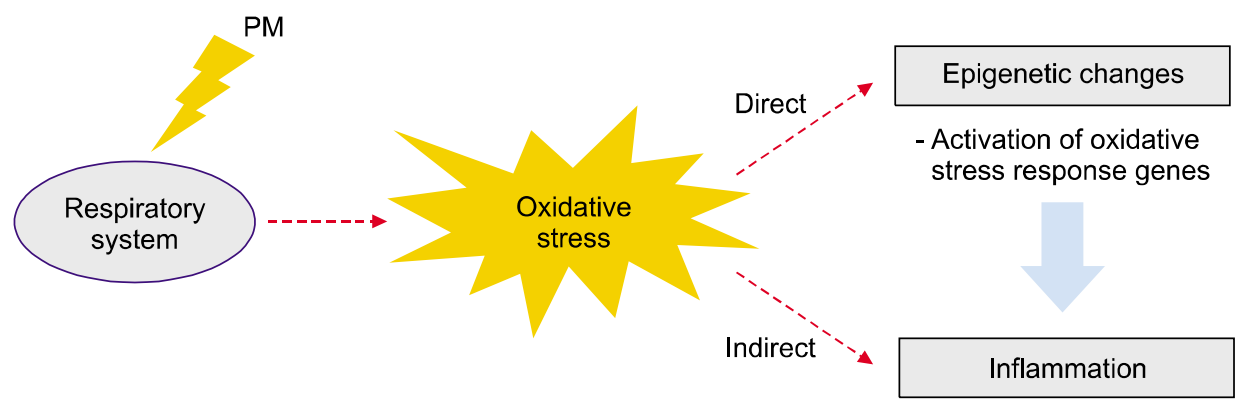

Respiratory diseases

- Lung cancer

- Asthma

- COPD

- Pneumonia
Figure 1. Schematic diagram of toxic effects of particulate matter (PM) on respiratory system. PM triggers oxidative stress in respiratory system, which induces epigenetic changes directly by activating oxidative stress response genes. Overproduced reactive oxygen species (ROS) and altered gene expressions can affect to inflammation indirectly as ROS stimulates signaling pathways. It contributes to development of respiratory diseases, such as asthma, chronic obstructive pulmonary disease (COPD), pneumonia, and lung cancer. 
oxidative stress causes various diseases, such as cancers, neurological diseases, heart diseases, atherosclerosis, and pulmonary disease. $^{39,40}$

It is well-known that PM induces oxidative stress in the lung. Because various chemicals and compounds, including PMs, can enter the airway directly, lung has a unique protecting system itself. $^{41}$ Higher glutathione (GSH) levels have been observed in alveolar epithelial surface (about 140 times higher than those of plasma). ${ }^{42-44} \mathrm{GSH}$ plays important role in protecting lungs against oxidative stress ${ }^{45}$ by returning oxidized cell constituents to reduced form and by detoxifying lipid hyperoxides or other oxidants. ${ }^{46}$ Thus, depletion of GSH is associated with disease development. Numerous studies have investigated the relationship between GSH level and disease development. ${ }^{47-50}$ In addition, when there are high levels of oxidative stress in lung tissue, neutrophils will arrive and become activated, which can produce more ROS. ${ }^{38}$ These over-produced ROS may cause oxidative stress, consequently leading to inflammatory response in the airway.

\section{Inflammation}

Inflammatory response is a process that react on tissues receiving harmful stimuli. It protects human body involving immune cells. It is activated when immune cells express pattern recognition receptor which binds to pathogen-associated molecular patterns, such as lipopolysaccharide. ${ }^{51}$ Besides, other stimuli, such as cytokines, can bind to plasma membrane or stress signal and activate inflammatory response. A number of kinases are associated with inflammatory response. ${ }^{52}$ Many studies have shown that inflammatory response is related to PM exposure. ${ }^{53}$ It has been reported that bacteria-derived endotoxin bound to the surface of PM particle is one of the causative agent in PM-mediated lung injury. ${ }^{54-56}$ As the major factor of PM induces lung toxicity, transition metal content of $\mathrm{PM}_{10}$ cause oxidative stress. ${ }^{57.58} \mathrm{Fe}$ and $\mathrm{Cu}$ are common chemicals inducing hydroxyl radical via Fenton reaction. When they are included in PM particles, ${ }^{59,60}$ they can induce oxidative stress and cause inflammatory diseases. ${ }^{61,62}$

In a recent animal study, PM exposure has been demonstrated to cause early immune suppression in severe allergic response of adult mouse. ${ }^{63} \mathrm{PM}$ affects specific antigen tolerance when the level of immunoglobulin $\mathrm{E}$ is elevated. It also increases the risks of asthma. $\mathrm{PM}_{10}$ change can induce cell proliferation, leading to cancer development. In addition, chemokines and selectins induced by inflammatory response can be used by cancer cells and increase malignant effects. Although inflammatory response prevents cancer development in some case, inflammatory response by PM exposure can lead to lung cancer. Exposure to low concentration of PM induces inflammatory response and damage to lung tissues of healthy mouse. ${ }^{64}$ In addition, when human lung epithelial cells are exposed to $\mathrm{PM}_{10}$, pyruvate kinase related to carcinogenesis is up-regulated while annextin 1, an anti-inflammation response protein, is down-regulated. ${ }^{53} \mathrm{PM}_{2.5}$ also induces inflammatory response as a result of oxidative stress caused by ROS. Oxidative stress changes the expression of proteins, such as NF-KB and interleukin (IL)-8 which are associated with inflammatory response. ${ }^{65}$

\section{Epigenetic change}

Epigenetic change means molecular change that regulates gene expression without changing DNA primary sequence. ${ }^{66}$ Epigenetic change is related to diverse biological mechanisms through alterations in gene expression or mRNA degradation. Epigenetic change occurs frequently by environmental factors, such as aging and diet. ${ }^{67,68}$ Recent studies have revealed that oxidative stress and redox status induced by PM regulates epigenetic changes, such as histone modification, methylation, acetylation, and chromatin remodeling. ${ }^{69-71}$

One of studies has shown that DNA methylation pattern in human is altered by exposure to traffic particles, such as PM and black carbon. ${ }^{72}$ Exposure to $\mathrm{PM}_{2.5}$ particles is associated with demethylation of long interspersed nucleotide element (LINE)-1. ${ }^{72}$ In addition, in in vitro and in vivo studies, black carbon, diesel exhausted particles (DEPs), and metal components of air pollutant particles, such as arsenic and cadmium, also induce DNA methylation. ${ }^{73,74}$ Several studies have suggested that histone modification is also induced by PM. For example, $\mathrm{PM}_{10}$ and DEP exposure have increased histone $\mathrm{H} 4$ acetylation at the IL-8 and COX-2 promoter in human lung and bronchial cells, respectively. ${ }^{75,76}$ Moreover, short-term exposure to PM can induces epigenetic changes, specifically in the promoter region of mitogen-activated protein kinase pathway genes such as LINE-1. ${ }^{71,72}$ These epigenetic changes might be associated with inflammation or increased oxidative stress. ${ }^{71}$ Thus, oxidative stress, inflammation, and epigenetic changes are intimately connected. They play important roles in the development and acceleration of respiratory diseases.

\section{RESPIRATORY DISEASE INDUCED BY PARTICULATE MATTER EXPOSURE}

Various lung diseases, such as COPD, asthma, and lung cancer, 
Table 1. Potential biomarkers of respiratory diseases induced by particulate matter

\begin{tabular}{|c|c|c|c|c|}
\hline Gene name & Description & Related process & Related disease & Reference \\
\hline CYP1A1 & $\begin{array}{l}\text { Cytochrome P450 family } 1 \text { subfamily } \\
\text { A member } 1\end{array}$ & $\begin{array}{l}\text { Oxidative stress } \\
\text { Inflammation }\end{array}$ & $\begin{array}{l}\text { Lung cancer } \\
\text { Asthma }\end{array}$ & 97 \\
\hline OGG1 & 8-oxoguanine DNA glycosylase & $\begin{array}{l}\text { Oxidative stress } \\
\text { Inflammation }\end{array}$ & $\begin{array}{l}\text { Lung cancer } \\
\text { Asthma } \\
\text { COPD }\end{array}$ & 88 \\
\hline IFNG & Interferon gamma & $\begin{array}{l}\text { Oxidative stress } \\
\text { Inflammation }\end{array}$ & $\begin{array}{l}\text { Lung cancer } \\
\text { Asthma } \\
\text { COPD }\end{array}$ & 97 \\
\hline TLR4 & Toll-like receptor 4 & $\begin{array}{l}\text { Oxidative stress } \\
\text { Inflammation }\end{array}$ & $\begin{array}{l}\text { Lung cancer } \\
\text { Asthma } \\
\text { COPD }\end{array}$ & 92 \\
\hline IL-13 & Interleukin 13 & $\begin{array}{l}\text { Oxidative stress } \\
\text { Inflammation }\end{array}$ & $\begin{array}{l}\text { Lung cancer } \\
\text { Asthma } \\
\text { COPD }\end{array}$ & 98 \\
\hline IL-10 & Interleukin 10 & $\begin{array}{l}\text { Oxidative stress } \\
\text { Inflammation }\end{array}$ & $\begin{array}{l}\text { Lung cancer } \\
\text { Asthma } \\
\text { COPD }\end{array}$ & 98 \\
\hline IL-4 & Interleukin 4 & $\begin{array}{l}\text { Oxidative stress } \\
\text { Inflammation }\end{array}$ & $\begin{array}{l}\text { Lung cancer } \\
\text { Asthma } \\
\text { COPD }\end{array}$ & 98 \\
\hline IL-13 & Interleukin 13 & $\begin{array}{l}\text { Oxidative stress } \\
\text { Inflammation }\end{array}$ & $\begin{array}{l}\text { Lung cancer } \\
\text { Asthma } \\
\text { COPD }\end{array}$ & 98 \\
\hline IL-6 & Interleukin 6 & $\begin{array}{l}\text { Oxidative stress } \\
\text { Inflammation }\end{array}$ & $\begin{array}{l}\text { Lung cancer } \\
\text { Asthma } \\
\text { COPD }\end{array}$ & 99 \\
\hline TNF & Tumor necrosis factor & $\begin{array}{l}\text { Oxidative stress } \\
\text { Inflammation }\end{array}$ & $\begin{array}{l}\text { Lung cancer } \\
\text { Asthma } \\
\text { COPD }\end{array}$ & 99 \\
\hline PDGFA & Platelet-derived growth factor subunit A & $\begin{array}{l}\text { Oxidative stress } \\
\text { Inflammation }\end{array}$ & $\begin{array}{l}\text { Lung cancer } \\
\text { Asthma }\end{array}$ & 99 \\
\hline TGFB1 & Transforming growth factor beta induced & $\begin{array}{l}\text { Oxidative stress } \\
\text { Inflammation }\end{array}$ & $\begin{array}{l}\text { Lung cancer } \\
\text { Asthma } \\
\text { COPD }\end{array}$ & 99 \\
\hline CSF2 & Colony stimulating factor 2 & $\begin{array}{l}\text { Oxidative stress } \\
\text { Inflammation }\end{array}$ & $\begin{array}{l}\text { Lung cancer } \\
\text { Asthma } \\
\text { COPD }\end{array}$ & 99 \\
\hline CXCL8 & C-X-C motif chemokine ligand 8 & $\begin{array}{l}\text { Oxidative stress } \\
\text { Inflammation }\end{array}$ & $\begin{array}{l}\text { Lung cancer } \\
\text { Asthma } \\
\text { COPD }\end{array}$ & 99 \\
\hline BMP4 & Bone morphogenetic protein 4 & $\begin{array}{l}\text { Oxidative stress } \\
\text { Inflammation }\end{array}$ & Lung cancer & 100 \\
\hline SMAD6 & SMAD family member 6 & Inflammation & & 100 \\
\hline ID1 & Inhibitor of DNA binding 1, HLH protein & $\begin{array}{l}\text { Oxidative stress } \\
\text { Inflammation }\end{array}$ & Lung cancer & 100 \\
\hline ID2 & Inhibitor of DNA binding 2, HLH protein & & Lung cancer & 100 \\
\hline GCLM & Glutamate-cysteine ligase modifier subunit & $\begin{array}{l}\text { Oxidative stress } \\
\text { Inflammation }\end{array}$ & & 100 \\
\hline HMOX1 & Heme oxygenase 1 & $\begin{array}{l}\text { Oxidative stress } \\
\text { Inflammation }\end{array}$ & $\begin{array}{l}\text { Lung cancer } \\
\text { Asthma } \\
\text { COPD }\end{array}$ & 100 \\
\hline SLC7A11 & Solute carrier family 7 member 11 & $\begin{array}{l}\text { Oxidative stress } \\
\text { Inflammation }\end{array}$ & Asthma & 100 \\
\hline SQSTM1 & Sequestosome 1 & $\begin{array}{l}\text { Oxidative stress } \\
\text { Inflammation }\end{array}$ & & 100 \\
\hline SRXN1 & Sulfiredoxin 1 & Oxidative stress & COPD & 100 \\
\hline
\end{tabular}


Table 1. Continued

\begin{tabular}{llllr}
\hline \multicolumn{1}{c}{ Gene name } & \multicolumn{1}{c}{ Description } & Related process & Related disease & Reference \\
\hline STC2 & Stanniocalcin 2 & Oxidative stress & Lung cancer & 100 \\
DNM1L & Dynamin 1 like & Oxidative stress & & 101 \\
FIS1 & Fission, mitochondrial 1 & Oxidative stress & COPD & 101 \\
MFN2 & Mitofusin 2 & Oxidative stress & Lung cancer & 101 \\
OPA1 & Mitochondrial dynamin like GTPase & Oxidative stress & & 101 \\
\hline
\end{tabular}

COPD, chronic obstructive pulmonary disease.

are related to PM exposure. ${ }^{77-79}$ COPD is a progressive disease causing abnormal inflammatory response by harmful particles or gas. It can lead symptoms, such as constantly cough, shortness of breath, wheezing, and chest tightness. ${ }^{80}$ When stable COPD patients are exposed to $\mathrm{PM}_{2.5}$, the number of patients who progress to acute exacerbation of COPD (AECOPD) is increased. ${ }^{7}$ It is caused by effects of $\mathrm{PM}_{2.5}$ exposure, such as increased phagocytosis, oxidant stress, and pro-inflammatory cytokines. One of epidemiologic investigations performed at Cleaveland, $\mathrm{OH}$ has revealed that risk of AECOPD was increased according to the concentration of $\mathrm{PM}_{2.5}{ }^{81}$ supporting the relationship between COPD and $\mathrm{PM}_{2.5}$ exposure.

Asthma is a chronic illness that makes the airway sensitive and narrow. Symptoms of this disease are coughing, shortness of breath, chest tightness, and wheezing. ${ }^{82}$ One study has suggested that increased exposure to $\mathrm{PM}_{10}$ and biological endotoxins are important factors in asthma pathogenesis. ${ }^{83} \mathrm{PM}_{10}$ induces pro-inflammatory response in lung tissue through toll-like receptor (TLR) pathway and affects NF-KB activation. It is probably one of the pathogenic factors of asthma. $\mathrm{PM}_{2.5}$ is also associated with the pathogenesis of asthma. ${ }^{84}$ Through meta-analysis using various database (PubMed, Ebsco, Ovid, and four Chinese), one study has shown that acute elevation of PM concentration in the air may increase hospital admission of Chinese children for asthma. ${ }^{84}$ When the concentration of $\mathrm{PM}_{2.5}$ is increased to $10 \mu \mathrm{g} / \mathrm{m}^{3}$, the increment of hospital admission for asthma is nearly twice than that when the concentration of $\mathrm{PM}_{10}$ is increased to $10 \mu \mathrm{g} / \mathrm{m}^{3}$. ${ }^{84}$

Lung cancer (also known as lung carcinoma) is one of the fatal cancers in worldwide. Lung cancer has two main types: small-cell lung carcinoma (SCLC) and non-small-cell lung carcinoma (NSCLC). ${ }^{1}$ WHO announced that cancer caused 8.2 million deaths in 2012 and lung cancer caused 1.59 million deaths. ${ }^{5}$ Among cancer deaths, lung cancer death had the highest number in 2012. ${ }^{5}$ A number of studies have determined the factors that lead to lung cancer. Through various studies, the causes of lung cancer include tobacco, radon gas, asbestos, genetic source, PM, and so on. Although major cause of lung cancer is known as smoking, recent studies have revealed that exposure to PM also leads to lung cancer. ${ }^{2.9}$ Lung cancer does not show initial symptom. Symptom of lung cancer is very similar to that of common cold. Thus, only a few patients are diagnosed of lung cancer at early stage. Most lung cancer patients are diagnosed after lung cancer has processed. As a result, untreated SCLC patients have a survival time of 6 to 17 weeks and treated SCLC patients have a survival periods of 40 to 70 weeks. ${ }^{85}$ Their 5 -year survival rate is lower than $10 \%$. The 5-years survival rate of all lung cancer patients (including male and female SCLC and NSCLS patients) during 2006 to 2010 year in South Korea was $19.7 \%{ }^{86}$ Therefore, it is important to prevent lung cancer to reduce mortality. Many clinical studies have reported the association between PM exposure and lung cancer occurrence. The concentrations of diverse compositions of PM have been measured by research staff at many cites. The long-term lung cancer occurrence rate and death rate are also recorded. Although detailed mechanisms of PM carcinogenic effect remain unclear, the relationship between PM and lung cancer is being studied by many institutions.

\section{BIOMARKERS OF LUNG DISEASES CAUSED BY PARTICULATE MATTER}

Genetic and epigenetic patterns associated with air pollutant, such as PM, might be useful biomarkers. ${ }^{87}$ Some studies have shown that epigenetic change caused by PM exposure can lead to increased susceptibility to lung diseases, including cancer. Epigenetic changes alter the expression of diverse genes and the regulation of mRNAs. Through screening of epigenetic patterns, it is possible to predict disease development of respiratory system. For this reason, biomarkers can be used to detect long-term effects of PM exposure. They are very useful for the prediction or early detection of respiratory diseases. Up to date, numerous studies have suggested that biomarkers are associated with PM exposure (Table 1, Fig. 2) ${ }^{88.93}$

It has been reported that 8-oxo-2'-deoxyguanosine (8-OHdG) is 


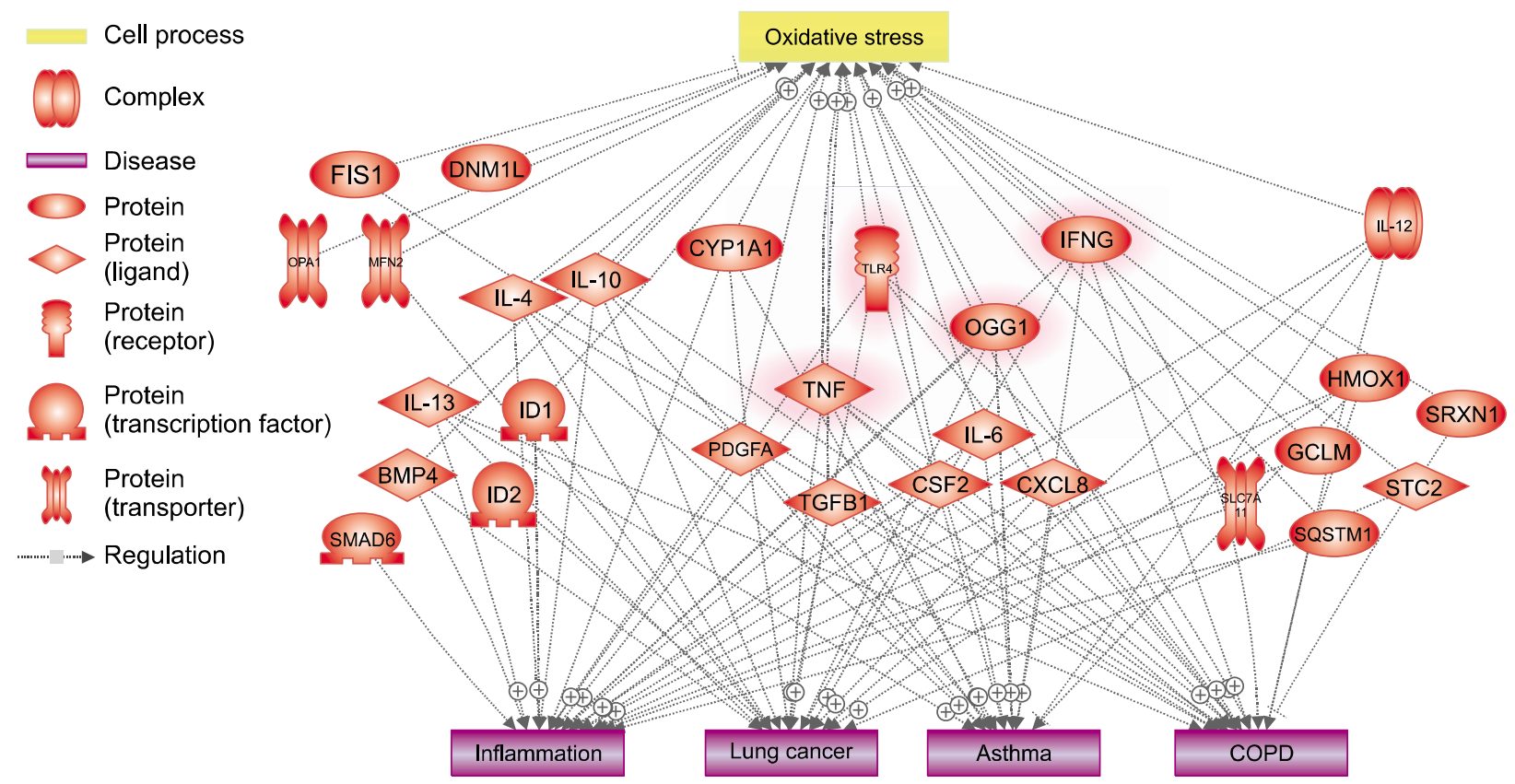

Figure 2. Related cell process and diseases with potential disease biomarkers induced by particulate matter visualized by Pathway Studio. Most of all proteins known as potential biomarker have relationship with oxidative stress and inflammation. Respiratory diseases also relates to diverse biomarkers. Highlighted proteins represents entire connection with cell process (oxidative stress) and diseases (inflammation, lung cancer, asthma, and COPD). FIS1, mitochondrial fission 1; DNM1L, dynamin 1 like; OPA1, mitochondrial dynamin like GTPase; MFN2, mitofusin 2; IL, interleukin; ID1, inhibitor of DNA binding 1, HLH protein; ID2, inhibitor of DNA binding 2, HLH protein; CYP1A1, cytochrome P450 family 1 subfamily A member 1; TLR4, toll-like receptor 4; IFNG, IFN gamma; OGG1, 8-oxoguanine DNA glycosylase; PDGFA, platelet-derived growth factor subunit A; TGFB1, transforming growth factor beta induced; CSF2, colony stimulating factor 2; CXCL8, C-X-C motif chemokine ligand 8; HMOX1, heme oxygenase 1; SRXN1, sulfiredoxin 1; GCLM, glutamate-cysteine ligase modifier subunit; SLC7A11, solute carrier family 7 member 11; STC2, stanniocalcin 2; SQSTM1, sequestosome 1; COPD, chronic obstructive pulmonary disease.

a biomarker of DNA damage. ${ }^{88.94} 8$-OHdG is one of several oxidative damage markers. It is induced by metal contents of PM, such as $\mathrm{Fe}, \mathrm{Cu}, \mathrm{Ni}$, and $\mathrm{Cd}$, in lung cells. Transition metals generates excessive ROS, which significantly increases oxidative stress. ${ }^{95.96}$ Formatted 8-OHdG causes DNA damage and mediate the cytotoxicity and carcinogenicity. ${ }^{88}$ LINE-1, one of oxidative damage-related markers, has been suggested as a gene expression and DNA methylation markers. ${ }^{71.72 .97}$ Other markers, such as Arthrobacter luteus restriction endonuclease (Alu) and TLR-4, also alters their gene expression levels in response to ambient particles. ${ }^{97}$ In addition, 8-oxoguanine DNA glycosylase (OGG1) is regarded as a DNA methylation biomarker based on previous studies. ${ }^{88}$ Takano et al. ${ }^{98}$ have demonstrated that cytochrome P450 1A1 is induced by DEP exposure in the lung. Biomarkers are induced by acute inhalation exposure to DEP and may result in ROS generation, subsequently causing lung injury. ${ }^{98}$ In field of toxicogenomics, global gene expression profiles have been well studied in diverse researches. ${ }^{99,100}$ These studies provide important information on biomarkers which can be used to predict the development of lung diseases. Biomarkers might play important role in preventing disease occurrence.

\section{CONCLUSION}

PM air pollutant is well known to have harmful components in many studies. It has been demonstrated that respiratory diseases and cardiovascular diseases are associated with exposure to PM. PMs can trigger pulmonary pathogenic effect and cause pulmonary disease subsequently. Lung is a core organ of the respiratory system. Once lung is damaged, it is very hard to recover to normal pulmonary function. ${ }^{101}$ COPD, asthma, and lung cancer, referred in this review as major pulmonary diseases, are all caused by PM exposure. Although diverse mechanisms are involved in PM-induced respiratory disease, there are three major mechanisms: induction of oxidative stress, inflammation, and epigenetic changes. Oxidative stress is a well-known cause of various diseases, especially cancer. PM induces oxidative stress in the lung by producing ROS which damages DNA and leads to apoptosis and other symptoms. In addition, oxidative stress may induces inflammatory injuries and epigenetic changes. There- 
fore, these three mechanisms are connected to each other. Biomarkers of PM-induced diseases are based on these mechanisms. Recently, toxicogenomic studies are being performed very actively due to recent development of genomic analysis tools. With this highly advanced genomic tools such as NGS, the new studies for finding biomarkers of PM-induced diseases can be conducted. Through such studies, if the most effective biomarkers can be identified, they will be useful for the prediction of PM-induced diseases and early detection. Eventually, studies on biomarkers will contribute to the prevention of lung diseases.

\section{ACKNOWLEDGMENTS}

This subject was supported by Korea Ministry of Environment (MOE) as "The Environmental Health Action Program" (2016001360009).

\section{CONFLICTS OF INTEREST}

No potential conflicts of interest were disclosed.

\section{REFERENCES}

1. Ekpenyong CE, Ettebong EO, Akpan EE, Samson TK, Daniel NE. Urban city transportation mode and respiratory health effect of air pollution: a cross-sectional study among transit and non-transit workers in Nigeria. BMJ Open 2012;2:e001253.

2. Lu X, Yao T, Fung JC, Lin C. Estimation of health and economic costs of air pollution over the Pearl River Delta region in China. Sci Total Environ 2016;566-567:134-43.

3. Behndig AF, Mudway IS, Brown JL, Stenfors N, Helleday R, Duggan ST, et al. Airway antioxidant and inflammatory responses to diesel exhaust exposure in healthy humans. Eur Respir J 2006;27:359-65.

4. Sydbom A, Blomberg A, Parnia S, Stenfors N, Sandström T, Dahlén SE. Health effects of diesel exhaust emissions. Eur Respir J 2001;17:733-46.

5. WHO. Burden of disease from Ambient Air Pollution for 2012. http://www.who.int/phe/health_topics/outdoorair/databases/ AAP_BoD_results_March2014.pdf?ua=1. Accessed 2012.

6. Blanchard CL, Tanenbaum S, Lawson DR. Differences between weekday and weekend air pollutant levels in Atlanta; Baltimore; Chicago; Dallas-Fort Worth; Denver; Houston; New York; Phoenix; Washington, DC; and surrounding areas. J Air Waste Manag Assoc 2008:58:1598-615.

7. Ni L, Chuang CC, Zuo L. Fine particulate matter in acute exacerbation of COPD. Front Physiol 2015;6:294.

8. Cui Y, Sun Q, Liu Z. Ambient particulate matter exposure and cardiovascular diseases: a focus on progenitor and stem cells. J Cell Mol Med 2016;20:782-93.

9. Neri T, Pergoli L, Petrini S, Gravendonk L, Balia C, Scalise V, et al. Particulate matter induces prothrombotic microparticle shedding by human mononuclear and endothelial cells. Toxicol In
Vitro 2016;32:333-8.

10. Barmpadimos I, Hueglin C, Keller J, Henne S, Prévôt ASH. Influence of meteorology on PM10 trends and variability in Switzerland from 1991 to 2008. Atmos Chem Phys 2011;11: 1813-35.

11. McBride AC, Dale VH, Baskaran LM, Downing ME, Eaton LM, Efroymson RA, et al. Indicators to support environmental sustainability of bioenergy systems. Ecol Indic 2011;11:1277-89.

12. EPA. Air Quality: EPA's 2013 Changes to the Particulate Matter (PM) Standard. https://www.fas.org/sgp/crs/misc/R42934.pdf. Accessed 2015.

13. Gugamsetty B, Wei H, Liu CN, Awasthi A, Hsu SC, Tsai CJ, et al. Source characterization and apportionment of PM10, PM2.5 and PM0.1 by using positive matrix factorization. Aerosol Air Qual Res 2012;12:476-91.

14. Saffari A, Daher N, Shafer MM, Schauer JJ, Sioutas C. Seasonal and spatial variation in dithiothreitol (DTT) activity of quasi-ultrafine particles in the Los Angeles Basin and its association with chemical species. J Environ Sci Health A Tox Hazard Subst Environ Eng 2014:49:441-51.

15. Samara C, Voutsa D. Size distribution of airborne particulate matter and associated heavy metals in the roadside environment. Chemosphere 2005:59:1197-206.

16. Atkinson RW, Fuller GW, Anderson HR, Harrison RM, Armstrong B. Urban ambient particle metrics and health: a time-series analysis. Epidemiology 2010;21:501-11.

17. Hirota JA, Marchant DJ, Singhera GK, Moheimani F, Dorscheid DR, Carlsten C, et al. Urban particulate matter increases human airway epithelial cell IL-1 $\beta$ secretion following scratch wounding and H1N1 influenza A exposure in vitro. Exp Lung Res 2015:41:353-62.

18. Gilmour PS, Schladweiler MC, Richards JH, Ledbetter AD, Kodavanti UP. Hypertensive rats are susceptible to TLR4-mediated signaling following exposure to combustion source particulate matter. Inhal Toxicol 2004;16 Suppl 1:5-18.

19. Clifford RL, Jones MJ, MacIsaac JL, McEwen LM, Goodman SJ, Mostafavi S, et al. Inhalation of diesel exhaust and allergen alters human bronchial epithelium DNA methylation. J Allergy Clin Immunol 2017;139:112-21.

20. Wang L, Zhao X, Xu W, Tang J, Jiang X. Correlation analysis of lung cancer and urban spatial factor: based on survey in Shanghai. J Thorac Dis 2016;8:2626-37.

21. Jansen KL, Larson TV, Koenig JQ, Mar TF, Fields C, Stewart J, et al. Associations between health effects and particulate matter and black carbon in subjects with respiratory disease. Environ Health Perspect 2005;113:1741-6.

22. Møller P, Jacobsen NR, Folkmann JK, Danielsen PH, Mikkelsen L, Hemmingsen JG, et al. Role of oxidative damage in toxicity of particulates. Free Radic Res 2010;44:1-46.

23. Lodovici M, Bigagli E. Oxidative stress and air pollution exposure. J Toxicol 2011;2011:487074.

24. Xu Z, Xu X, Zhong M, Hotchkiss IP, Lewandowski RP, Wagner JG, et al. Ambient particulate air pollution induces oxidative stress and alterations of mitochondria and gene expression in brown and white adipose tissues. Part Fibre Toxicol 2011;8:20.

25. van Eeden SF, Tan WC, Suwa T, Mukae H, Terashima T, Fujii T, et al. Cytokines involved in the systemic inflammatory response induced by exposure to particulate matter air pollutants (PM(10)). Am J Respir Crit Care Med 2001;164:826-30. 
26. Gavett SH, Koren HS. The role of particulate matter in exacerbation of atopic asthma. Int Arch Allergy Immunol 2001;124:109-12.

27. Tecer LH, Alagha O, Karaca F, Tuncel G, Eldes N. Particulate matter (PM(2.5), $\mathrm{PM}(10-2.5)$, and $\mathrm{PM}(10))$ and children's hospital admissions for asthma and respiratory diseases: a bidirectional case-crossover study. J Toxicol Environ Health A 2008;71:512-20.

28. Ling SH, van Eeden SF. Particulate matter air pollution exposure: role in the development and exacerbation of chronic obstructive pulmonary disease. Int J Chron Obstruct Pulmon Dis 2009:4:233-43.

29. van Eeden SF, Yeung A, Quinlam K, Hogg JC. Systemic response to ambient particulate matter: relevance to chronic obstructive pulmonary disease. Proc Am Thorac Soc 2005;2:61-7.

30. de Hartog JJ, Ayres JG, Karakatsani A, Analitis A, Brink HT, Hameri $\mathrm{K}$, et al. Lung function and indicators of exposure to indoor and outdoor particulate matter among asthma and COPD patients. Occup Environ Med 2010;67:2-10.

31. Donaldson K, Stone V, Borm PJ, Jimenez LA, Gilmour PS, Schins $\mathrm{RP}$, et al. Oxidative stress and calcium signaling in the adverse effects of environmental particles (PM10). Free Radic Biol Med 2003:34:1369-82.

32. Kawanishi S, Hiraku Y, Oikawa S. Mechanism of guanine-specific DNA damage by oxidative stress and its role in carcinogenesis and aging. Mutat Res 2001:488:65-76.

33. Kryston TB, Georgiev AB, Pissis P, Georgakilas AG. Role of oxidative stress and DNA damage in human carcinogenesis. Mutat Res 2011;711:193-201.

34. Au WW. Usefulness of biomarkers in population studies: from exposure to susceptibility and to prediction of cancer. Int J Hyg Environ Health 2007;210:239-46.

35. van der Velde AR, Meijers WC, de Boer RA. Biomarkers for risk prediction in acute decompensated heart failure. Curr Heart Fail Rep 2014;11:246-59.

36. Hou L, Zhang X, Tarantini L, Nordio F, Bonzini M, Angelici L, et al. Ambient PM exposure and DNA methylation in tumor suppressor genes: a cross-sectional study. Part Fibre Toxicol 2011;8:25.

37. Liu C, Xu J, Chen Y, Guo X, Zheng Y, Wang Q, et al. Characterization of genome-wide $\mathrm{H} 3 \mathrm{~K} 27 \mathrm{ac}$ profiles reveals a distinct PM2.5-associated histone modification signature. Environ Health 2015;14:65.

38. Gomes EC, Florida-James G. Lung inflammation, oxidative stress and air pollution. In: Lung Inflammation. Rijeka, InTech, 2014.

39. Powers SK, DeRuisseau KC, Quindry J, Hamilton KL. Dietary antioxidants and exercise. J Sports Sci 2004:22:81-94.

40. Halliwell B, Gutteridge JMC. Free radicals in biology and medicine. 3rd ed. New York, Oxford University Press, 2007.

41. Boyd MR, Stiko A, Statham CN, Jones RB. Protective role of endogenous pulmonary glutathione and other sulfhydryl compounds against lung damage by alkylating agents. Investigations with 4-ipomeanol in the rat. Biochem Pharmacol 1982;31:1579-83.

42. Griffith OW, Bridges RJ, Meister A. Transport of gamma-glutamyl amino acids: role of glutathione and gamma-glutamyl transpeptidase. Proc Natl Acad Sci U S A 1979;76:6319-22.

43. Cantin AM, Bégin R. Glutathione and inflammatory disorders of the lung. Lung 1991;169:123-38.

44. Meister A. New aspects of glutathione biochemistry and transport: selective alteration of glutathione metabolism. Fed Proc
1984:43:3031-42.

45. Ray LE, Prescott JM. Isolation and some characteristics of glutathione reductase from rabbit erythrocytes (38548). Proc Soc Exp Biol Med 1975;148:402-9.

46. Rahman Q, Abidi P, Afaq F, Schiffmann D, Mossman BT, Kamp DW, et al. Glutathione redox system in oxidative lung injury. Crit Rev Toxicol 1999:29:543-68.

47. Rahman I, MacNee W. Lung glutathione and oxidative stress: implications in cigarette smoke-induced airway disease. Am J Physiol 1999;277:L1067-88.

48. Moss M, Guidot DM, Wong-Lambertina M, Ten Hoor T, Perez RL, Brown LA. The effects of chronic alcohol abuse on pulmonary glutathione homeostasis. Am J Respir Crit Care Med 2000;161: 414-9.

49. Smith CV, Jones DP, Guenthner TM, Lash LH, Lauterburg BH. Compartmentation of glutathione: implications for the study of toxicity and disease. Toxicol Appl Pharmacol 1996;140:1-12.

50. Dalton TP, Chen Y, Schneider SN, Nebert DW, Shertzer HG. Genetically altered mice to evaluate glutathione homeostasis in health and disease. Free Radic Biol Med 2004:37:1511-26.

51. Lee JY, Zhao L, Youn HS, Weatherill AR, Tapping R, Feng L, et al. Saturated fatty acid activates but polyunsaturated fatty acid inhibits Toll-like receptor 2 dimerized with Toll-like receptor 6 or 1. J Biol Chem 2004:279:16971-9.

52. Sopko R, Andrews BJ. Linking the kinome and phosphorylome--a comprehensive review of approaches to find kinase targets. Mol Biosyst 2008:4:920-33.

53. Jeon YM, Son BS, Lee MY. Proteomic identification of the differentially expressed proteins in human lung epithelial cells by airborne particulate matter. J Appl Toxicol 2011;31:45-52.

54. Becker S, Soukup JM, Gilmour MI, Devlin RB. Stimulation of human and rat alveolar macrophages by urban air particulates: effects on oxidant radical generation and cytokine production. Toxicol Appl Pharmacol 1996;141:637-48.

55. Dong W, Lewtas J, Luster MI. Role of endotoxin in tumor necrosis factor alpha expression from alveolar macrophages treated with urban air particles. Exp Lung Res 1996:22:577-92.

56. Long CM, Suh HH, Kobzik L, Catalano PJ, Ning YY, Koutrakis P. A pilot investigation of the relative toxicity of indoor and outdoor fine particles: in vitro effects of endotoxin and other particulate properties. Environ Health Perspect 2001;109:1019-26.

57. Frampton MW, Ghio AJ, Samet JM, Carson JL, Carter JD, Devlin RB. Effects of aqueous extracts of PM(10) filters from the Utah valley on human airway epithelial cells. Am J Physiol 1999; 277:L960-7.

58. Ghio AJ, Devlin RB. Inflammatory lung injury after bronchial instillation of air pollution particles. Am J Respir Crit Care Med 2001; 164:704-8.

59. Halliwell B, Gutteridge JM. Free radicals in biology and medicine. 2nd ed. Oxford, Clarendon Press, 1989.

60. Lloyd RV, Hanna PM, Mason RP. The origin of the hydroxyl radical oxygen in the Fenton reaction. Free Radic Biol Med 1997; 22:885-8.

61. Harrison RM, Yin J. Particulate matter in the atmosphere: which particle properties are important for its effects on health? Sci Total Environ 2000;249:85-101.

62. Lloyd DR, Carmichael PL, Phillips DH. Comparison of the formation of 8-hydroxy-2'-deoxyguanosine and single- and double-strand breaks in DNA mediated by fenton reactions. Chem 
Res Toxicol 1998:11:420-7.

63. Saravia J, You D, Thevenot P, Lee GI, Shrestha B, Lomnicki S, et al. Early-life exposure to combustion-derived particulate matter causes pulmonary immunosuppression. Mucosal Immunol 2014;7:694-704.

64. Riva DR, Magalhães CB, Lopes AA, Lanças T, Mauad T, Malm O, et al. Low dose of fine particulate matter (PM2.5) can induce acute oxidative stress, inflammation and pulmonary impairment in healthy mice. Inhal Toxicol 2011;23:257-67.

65. Ma J, Xu H, Wu J, Qu C, Sun F, Xu S. Linalool inhibits cigarette smoke-induced lung inflammation by inhibiting NF-KB activation. Int Immunopharmacol 2015;29:708-13.

66. Loke YJ, Hannan AJ, Craig JM. The role of epigenetic change in autism spectrum disorders. Front Neurol 2015;6:107.

67. Fraga MF, Ballestar E, Paz MF, Ropero S, Setien F, Ballestar ML, et al. Epigenetic differences arise during the lifetime of monozygotic twins. Proc Natl Acad Sci U S A 2005:102:10604-9.

68. Bjornsson HT, Sigurdsson MI, Fallin MD, Irizarry RA, Aspelund $\mathrm{T}$, Cui $\mathrm{H}$, et al. Intra-individual change over time in DNA methylation with familial clustering. JAMA 2008:299:2877-83.

69. Rahman I, MacNee W. Role of transcription factors in inflammatory lung diseases. Thorax 1998;53:601-12.

70. Kamata H, Honda S, Maeda S, Chang L, Hirata H, Karin M. Reactive oxygen species promote TNFalpha-induced death and sustained JNK activation by inhibiting MAP kinase phosphatases. Cell 2005;120:649-61.

71. Carmona JJ, Sofer T, Hutchinson J, Cantone L, Coull B, Maity A, et al. Short-term airborne particulate matter exposure alters the epigenetic landscape of human genes associated with the mitogen-activated protein kinase network: a cross-sectional study. Environ Health 2014;13:94.

72. Baccarelli A, Wright RO, Bollati V, Tarantini L, Litonjua AA, Suh $\mathrm{HH}$, et al. Rapid DNA methylation changes after exposure to traffic particles. Am J Respir Crit Care Med 2009;179:572-8.

73. Belinsky SA, Snow SS, Nikula KJ, Finch GL, Tellez CS, Palmisano WA. Aberrant CpG island methylation of the p16(INK4a) and estrogen receptor genes in rat lung tumors induced by particulate carcinogens. Carcinogenesis 2002;23:335-9.

74. Wright RO, Baccarelli A. Metals and neurotoxicology. J Nutr 2007; 137:2809-13.

75. Gilmour PS, Rahman I, Donaldson K, MacNee W. Histone acetylation regulates epithelial IL- 8 release mediated by oxidative stress from environmental particles. Am J Physiol Lung Cell Mol Physiol 2003;284:L533-40.

76. Cao D, Bromberg PA, Samet JM. COX-2 expression induced by diesel particles involves chromatin modification and degradation of HDAC1. Am J Respir Cell Mol Biol 2007;37:232-9.

77. Stevanović I, Jovasević-Stojanović M, Stosić JJ. Association between ambient air pollution, meteorological conditions and exacerbations of asthma and chronic obstructive pulmonary disease in adult citizens of the town of Smederevo. Vojnosanit Pregl 2016;73:152-8.

78. Schwartz J. Particulate air pollution and chronic respiratory disease. Environ Res 1993;62:7-13.

79. Raaschou-Nielsen O, Beelen R, Wang M, Hoek G, Andersen Z], Hoffmann B, et al. Particulate matter air pollution components and risk for lung cancer. Environ Int 2016;87:66-73.

80. Higenbottam T. Chronic cough and the cough reflex in common lung diseases. Pulm Pharmacol Ther 2002;15:241-7.
81. Kumar N, Liang D, Comellas A, Chu AD, Abrams T. Satellite-based PM concentrations and their application to COPD in Cleveland, OH. J Expo Sci Environ Epidemiol 2013;23:637-46.

82. Globe G, Martin M, Schatz M, Wiklund I, Lin J, von Maltzahn R, et al. Symptoms and markers of symptom severity in asthma--content validity of the asthma symptom diary. Health Qual Life Outcomes 2015;13:21.

83. Ortiz-Martínez MG, Rodríguez-Cotto RI, Ortiz-Rivera MA, Pluguez-Turull CW, Jiménez-Vélez BD. Linking endotoxins, African Dust PM10 and Asthma in an urban and rural environment of Puerto Rico. Mediators Inflamm 2015;2015:784212.

84. Ding L, Zhu D, Peng D. Meta-analysis of the relationship between particulate matter (PM(10) and $\mathrm{PM}(2.5))$ and asthma hospital admissions in children. Zhonghua Er Ke Za Zhi 2015; 53:129-35.

85. Lee JE, Park HS, Jung SS, Kim JO, Kim SY. Phase II study of a 3-week schedule of irinotecan combined with cisplatin in previously untreated extensive-stage small-cell lung cancer. Oncology 2007;73:76-80.

86. Jung KW, Won YJ, Kong HJ, Oh CM, Shin A, Lee JS. Survival of Korean adult cancer patients by stage at diagnosis, 2006-2010: national cancer registry study. Cancer Res Treat 2013:45:162-71.

87. Ho SM. Environmental epigenetics of asthma: an update. J Allergy Clin Immunol 2010;126:453-65.

88. Hemmingsen JG, Jantzen K, Møller P, Loft S. No oxidative stress or DNA damage in peripheral blood mononuclear cells after exposure to particles from urban street air in overweight elderly. Mutagenesis 2015:30:635-42.

89. Totlandsdal AI, Cassee FR, Schwarze P, Refsnes M, Låg M. Diesel exhaust particles induce CYP1A1 and pro-inflammatory responses via differential pathways in human bronchial epithelial cells. Part Fibre Toxicol 2010;7:41.

90. He M, Ichinose T, Yoshida S, Nishikawa M, Mori I, Yanagisawa $\mathrm{R}$, et al. Urban particulate matter in Beijing, China, enhances allergen-induced murine lung eosinophilia. Inhal Toxicol 2010; 22:709-18

91. Fujii T, Hayashi S, Hogg JC, Vincent R, Van Eeden SF. Particulate matter induces cytokine expression in human bronchial epithelial cells. Am J Respir Cell Mol Biol 2001;25:265-71.

92. Sun H, Shamy M, Kluz T, Muñoz AB, Zhong M, Laulicht F, et al. Gene expression profiling and pathway analysis of human bronchial epithelial cells exposed to airborne particulate matter collected from Saudi Arabia. Toxicol Appl Pharmacol 2012;265: 147-57.

93. Li R, Kou X, Geng H, Xie J, Yang Z, Zhang Y, et al. Effect of ambient $\operatorname{PM}(2.5)$ on lung mitochondrial damage and fusion/fission gene expression in rats. Chem Res Toxicol 2015:28:408-18.

94. Valavanidis A, Vlahoyianni T, Fiotakis K. Comparative study of the formation of oxidative damage marker 8-hydroxy-2'-deoxyguanosine (8-OHdG) adduct from the nucleoside 2'-deoxyguanosine by transition metals and suspensions of particulate matter in relation to metal content and redox reactivity. Free Radic Res 2005;39:1071-81.

95. Tsou TC, Chen CL, Liu TY, Yang JL. Induction of 8-hydroxydeoxyguanosine in DNA by chromium(III) plus hydrogen peroxide and its prevention by scavengers. Carcinogenesis 1996;17:103-8.

96. Prahalad AK, Inmon J, Dailey LA, Madden MC, Ghio AJ, Gallagher JE. Air pollution particles mediated oxidative DNA base damage in a cell free system and in human airway epi- 
thelial cells in relation to particulate metal content and bioreactivity. Chem Res Toxicol 2001;14:879-87.

97. Bellavia A, Urch B, Speck M, Brook RD, Scott JA, Albetti B, et al. DNA hypomethylation, ambient particulate matter, and increased blood pressure: findings from controlled human exposure experiments. J Am Heart Assoc 2013;2:e000212.

98. Takano H, Yanagisawa R, Ichinose T, Sadakane K, Inoue K, Yoshida S, et al. Lung expression of cytochrome P450 1A1 as a possible biomarker of exposure to diesel exhaust particles. Arch
Toxicol 2002:76:146-51.

99. Chu JH, Hart JE, Chhabra D, Garshick E, Raby BA, Laden F. Gene expression network analyses in response to air pollution exposures in the trucking industry. Environ Health 2016;15:101.

100. Wang T, Garcia JG, Zhang W. Epigenetic regulation in particulate matter-mediated cardiopulmonary toxicities: a systems biology perspective. Curr Pharmacogenomics Person Med 2012;10:314-21.

101. Crosbie WA, Snowden S, Parsons V. Changes in lung capillary permeability in renal failure. Br Med J 1972;4:388-90. 